\title{
A dated phylogeny and collection records reveal repeated biome shifts in the African genus Coccinia (Cucurbitaceae)
}

\author{
Norbert Holstein*, Susanne S Renner
}

\begin{abstract}
Background: Conservatism in climatic tolerance may limit geographic range expansion and should enhance the effects of habitat fragmentation on population subdivision. Here we study the effects of historical climate change, and the associated habitat fragmentation, on diversification in the mostly sub-Saharan cucurbit genus Coccinia, which has 27 species in a broad range of biota from semi-arid habitats to mist forests. Species limits were inferred from morphology, and nuclear and plastid DNA sequence data, using multiple individuals for the widespread species. Climatic tolerances were assessed from the occurrences of 1189 geo-referenced collections and WorldClim variables.

Results: Nuclear and plastid gene trees included 35 or 65 accessions, representing up to 25 species. The data revealed four species groups, one in southern Africa, one in Central and West African rain forest, one widespread but absent from Central and West African rain forest, and one that occurs from East Africa to southern Africa. A few individuals are differently placed in the plastid and nuclear (LFY) trees or contain two ITS sequence types, indicating hybridization. A molecular clock suggests that the diversification of Coccinia began about 6.9 Ma ago, with most of the extant species diversity dating to the Pliocene. Ancestral biome reconstruction reveals six switches between semi-arid habitats, woodland, and forest, and members of several species pairs differ significantly in their tolerance of different precipitation regimes.

Conclusions: The most surprising findings of this study are the frequent biome shifts (in a relatively small clade) over just 6 - 7 million years and the limited diversification during and since the Pleistocene. Pleistocene climate oscillations may have been too rapid or too shallow for full reproductive barriers to develop among fragmented populations of Coccinia, which would explain the apparently still ongoing hybridization between certain species. Steeper ecological gradients in East Africa and South Africa appear to have resulted in more advanced allopatric speciation there.
\end{abstract}

\section{Background}

Clades will typically retain their ecological characteristics, at least over moderate periods of evolutionary time $[1,2]$, and where inherited climatic tolerances are narrow, this will limit species' geographic range expansion. As long as the inherited component of ecological preference is strong, species evolving in allopatry should initially have similar habitat requirements, and ecological differences between them should accumulate gradually [3]. These arguments set up expectations about how

\footnotetext{
* Correspondence: holstein@lrz.uni-muenchen.de
Systematic Botany and Mycology, University of Munich (LMU), Menzinger

* Correspondence: holstein@lrz.uni-muenchen.de
Systematic Botany and Mycology, University of Munich (LMU), Menzinger Strasse 67, Munich, Germany
} Strasse 67, Munich, Germany

climate niches and species ranges in groups of related species should correlate with each other. Phylogeographic analyses of several African plant clades have found strong signal of Neogene habitat fragmentation and opportunity for allopatric speciation [4-8], but provided no quantitative data on ecological requirements of the species involved. Davis et al. [9] in their study of 11 species of the Malpighiaceae genus Acridocarpus showed that aridification in Eastern Africa apparently was accompanied by a small radiation, possibly involving niche shifts, but did not have details on species' drought tolerances. For a clade of tropical African Annonaceae, Couvreur et al. [10] inferred divergence events between 
East and West African rainforest species during the Pliocene and Miocen, but provided no data on niche shifts. A likely reason for the comparative neglect of tropical African plant groups in eco-evolutionary studies is that ranges are poorly known because the underlying occurrence data are too incomplete $[11,12]$. Related problems are a lack of monographic studies, poorly understood species boundaries, and few species-level phylogenies, the precondition for identifying sister species.

While African plant clades are thus underrepresented in eco-phylogenetic studies, the immense interest in primate evolution in Africa has resulted in a wealth of data on vegetation and climate history [13-15]. During the Middle Miocene, starting from about $16 \mathrm{Ma}$ onwards, the African continent underwent gradual cooling and uplift in the east and south, leading to an expansion of woodlands and savannas, and reducing the ranges of lowland rain forest species [15-17]. By the Upper Miocene, $7 \mathrm{Ma}$ ago, rifting and volcanism blocked precipitation, amplifying the overall aridification in East Africa $[18,19]$. The early Pliocene brought slightly warmer climates until c. $3.2 \mathrm{Ma}$ [20], when the African tropics began experiencing dramatic climate changes that lasted throughout the Pleistocene and Holocene [21-24]. During the driest and coolest periods of the Pleistocene (2.6 Ma - 12,000 years ago), rain forests may have been restricted to refugia from which they re-expanded during more favorable periods [25-28]. The Quaternary climate oscillations affected all of equatorial Africa [29], with the most recent catastrophic destruction of rain forest occurring 2500 years ago [30].

Here we investigate clade diversification and changes in species' precipitation niches in the African cucurbit genus Coccinia. Coccinia comprises 27 species (all of them dioecious) and is almost confined to sub-Saharan Africa where it diversified into numerous habitat types. The only species that "escaped" from sub-Saharan Africa is C. grandis, which spread to the highlands of the Arabian Peninsula and tropical Asia, and is now an invasive weed on the Pacific Islands and in the Neotropics [31]. Pollination of Coccinia is by bees [[32]; NH, personal observation in Tanzania, August 2009], including honeybees. The numerous habitat types occupied by its 27 species make Coccinia a suiTable system in which to study niche evolution among close relatives. The niche parameters we focus on are annual precipitation and number of arid months, with species' tolerances being inferred from the occurrences of 1189 geo-referenced collections. Likely past changes in species' ecological preferences were inferred from a time-calibrated molecular tree including all but two of the species. We expected that close relatives would have similar climatic niche envelopes (e.g., drought tolerances), although clearly there had to have been at least two shifts since different Coccinia species occur in semi-arid habitats, woodland, and forest, vegetation types with contrasting precipitation regimes.

\section{Results \\ Phylogenetic Reconstruction and Divergence Time Estimates}

The concatenated plastid DNA alignment comprised 4551 nucleotides from 65 accessions representing 25 of the 27 species of Coccinia. Table 1 lists all DNA sources with their geographic origin, species name and author, and GenBank accession numbers. A maximum likelihood tree (Figure 1) obtained from the plastid data (TreeBASE accession 10846) shows four major groups: A quinqueloba group that occurs in southern Africa, a barteri clade that mostly occurs in Central and West African rain forest, an adoensis clade that is widespread, but absent from Central and West African rain forest, and a rehmannii clade that occurs from Ethiopia via East Africa to southern Africa.

The nuclear $L F Y 2^{\text {nd }}$ intron alignment (TreeBASE accession 10846) comprised 463 characters for 35 accessions, representing 20 species of Coccinia plus three outgroups. A maximum likelihood tree from these data (Figure 2) does not contradict the plastid tree topology except for a few accessions in the C. adoensis and C. barteri clades discussed below, and an accession of C. sessilifolia, which in the nuclear tree groups with the quinqueloba group, but in the plastid tree groups with the adoensis clade.

A tree from the nuclear ITS alignment is almost unresolved (data not shown), but ITS sequences helped pinpoint suspected hybridization (Figure 3; see the section on Evidence for Hybridization). For example, individuals of C. adoensis from different parts of the species' range have different ITS sequences.

A chronogram from a slightly reduced plastid DNA data set (Figure 4a) shows the inferred absolute ages (with 95\% confidence intervals) for nodes with $>0.98$ posterior probability. The diversification of Coccinia apparently began 6.9 Ma ago (10.2 - 3.9 Ma, 95\% highest posterior density [HPD]), with most of the extant species diversity dating to the Pliocene.

\section{Climatic Tolerances and Biome Preferences among Close Relatives}

Differences in climatic tolerances for species in wellsupported clades were quantified by pair-wise MannWhitney $U$ tests, focusing on annual precipitation and number of arid months (Table $2 \mathrm{a}-\mathrm{c}$ ). After each species or unit (in the case of the three genotypes of C. adoensis) had been assigned to one of three habitat categories (semi-arid habitats, woodland, or forest; see Methods), maximum likelihood inference of habitat 
Table 1 Voucher information and GenBank accession numbers

\begin{tabular}{|c|c|c|c|c|c|c|c|c|c|c|c|}
\hline Species & No. & Voucher & Location & matK & $\begin{array}{l}\text { ndhF- } \\
r p / 32 \mathrm{R} \text { IS }\end{array}$ & $\begin{array}{l}\text { rp/20- } \\
\text { rps } 12 \text { IS }\end{array}$ & $\begin{array}{l}\text { trnL } \\
\text { intron }\end{array}$ & $\begin{array}{l}\text { trnL- trnF } \\
\text { IS }\end{array}$ & $\begin{array}{l}\text { trnS- trnG } \\
\text { IS }\end{array}$ & $\begin{array}{l}L F Y 2^{\text {nd }} \\
\text { intron }\end{array}$ & ITS \\
\hline C. abyssinica (Lam.) Cogn. & 1 & $\begin{array}{l}\text { E. Westphal \& J. M. C. } \\
\text { Westphal-Stevels } 1552 \\
\text { (WAG) }\end{array}$ & Ethiopia, Oromia Region & HQ608224 & & HQ608311 & & & HQ608429 & & \\
\hline C. abyssinica (Lam.) Cogn. & 2 & $\begin{array}{l}\text { E. Westphal \& J. M. C. } \\
\text { Westphal-Stevels } 1951 \\
\text { (WAG) }\end{array}$ & Ethiopia, Oromia Region & & & HQ608312 & HQ608385 & HQ608368 & HQ608430 & & \\
\hline $\begin{array}{l}\text { C. adoensis (Hochst. ex A. } \\
\text { Rich.) Cogn. }\end{array}$ & 1 & L. E. Davidson 3781 (M) & South Africa, Gauteng & HQ608226 & HQ608274 & HQ608314 & HQ608396 & HQ608396 & HQ608432 & & HQ608195 \\
\hline $\begin{array}{l}\text { C. adoensis (Hochst. ex A. } \\
\text { Rich.) Cogn. }\end{array}$ & 2 & R. Story $6283(\mathrm{M})$ & Namibia, Otjozondjupa & HQ608227 & HQ608275 & HQ608316 & HQ608397 & HQ608397 & HQ608434 & HQ608160 & $\begin{array}{l}\text { HQ608196 } \\
-8\end{array}$ \\
\hline $\begin{array}{l}\text { C. adoensis (Hochst. ex A. } \\
\text { Rich.) Cogn. }\end{array}$ & 3 & J. Pawek 6124 (MO) & Malawi, Northern Region & HQ608225 & & HQ608315 & & HQ608369 & HQ608433 & & \\
\hline $\begin{array}{l}\text { C. adoensis (Hochst. ex A. } \\
\text { Rich.) Cogn. }\end{array}$ & 4 & $\begin{array}{l}\text { R. E. Gereau \& C. J. } \\
\text { Kayombo } 3582 \text { (MO) }\end{array}$ & Tanzania, Iringa & HQ608231 & HQ608273 & HQ608313 & & & HQ608431 & & \\
\hline $\begin{array}{l}\text { C. adoensis (Hochst. ex A. } \\
\text { Rich.) Cogn. }\end{array}$ & 5 & E. A. Robinson 2944 (M) & Zambia, Southern Prov. & HQ608228 & & HQ608318 & HQ608398 & HQ608398 & HQ608436 & & $\begin{array}{l}\text { HQ608199 } \\
-201\end{array}$ \\
\hline $\begin{array}{l}\text { C. adoensis (Hochst. ex A. } \\
\text { Rich.) Cogn. }\end{array}$ & 6 & H. Merxmüller 282 (M) & South Africa, Gauteng & HQ608229 & & HQ608319 & & HQ608370 & HQ608437 & & \\
\hline $\begin{array}{l}\text { C. adoensis (Hochst. ex A. } \\
\text { Rich.) Cogn. }\end{array}$ & 7 & M. Sanane 375 (M) & Zambia, Northern Prov. & HQ608230 & & HQ608320 & HQ608399 & HQ608399 & HQ608438 & & \\
\hline $\begin{array}{l}\text { C. adoensis (Hochst. ex A. } \\
\text { Rich.) Cogn. }\end{array}$ & 8 & A. R. Torre 5337 (M) & Mozambique, Zambezia & & & HQ608321 & & HQ608371 & HQ608439 & & \\
\hline $\begin{array}{l}\text { C. adoensis (Hochst. ex A. } \\
\text { Rich.) Cogn. }\end{array}$ & 9 & $\begin{array}{l}\text { D. K. Harder \& M. G. } \\
\text { Bingham } 2584 \text { (MO) }\end{array}$ & Zambia, Lusaka Prov. & HQ608268 & HQ608299 & HQ608364 & & & HQ608492 & HQ608191 & HQ608221 \\
\hline C. aurantiaca C. Jeffrey & 1 & M. Richards 20987 (BR) & Tanzania, Iringa & HQ608235 & & HQ625507 & HQ608401 & HQ608401 & HQ608443 & & \\
\hline C. aurantiaca C. Jeffrey & 2 & $\begin{array}{l}\text { P. J. Greenway \& Kanuri } \\
14811 \text { (M) }\end{array}$ & Tanzania, Iringa & & & & HQ608402 & HQ608402 & HQ608444 & HQ608161 & HQ608202 \\
\hline C. aurantiaca C. Jeffrey & 3 & N. Holstein et al. 86 (M) & Tanzania, Dodoma & HQ608236 & HQ608276 & HQ608325 & HQ608403 & HQ608403 & HQ608445 & HQ608162 & \\
\hline C. aurantiaca C. Jeffrey & 4 & S. A. Robertson 1925 (MO) & Kenya, Eastern Prov. & HQ608232 & & HQ608322 & HQ608400 & HQ608400 & HQ608440 & & \\
\hline C. barteri (Hook. f.) Keay & 1 & $\begin{array}{l}\text { E. Achigan-Dako } 07 \text { NIA } \\
899 \text { (GAT) }\end{array}$ & Guinea, Nzérékoré Region & HQ608237 & & HQ608330 & HQ608404 & HQ608404 & HQ608450 & & HQ608203 \\
\hline C. barteri (Hook. f.) Keay & 2 & J. J. Wieringa 6387 (WAG) & Gabon, Haut-Ogooué & HQ608239 & HQ608277 & HQ608326 & HQ608405 & HQ608405 & HQ608446 & HQ608163 & HQ608204 \\
\hline C. barteri (Hook. f.) Keay & 3 & $\begin{array}{l}\text { E. Achigan-Dako } 06 \text { NIA } \\
294 \text { (GAT) }\end{array}$ & Guinea, Mamou Region & & & HQ608331 & HQ608389 & HQ608376 & HQ608451 & & \\
\hline C. barteri (Hook. f.) Keay & 4 & $\begin{array}{l}\text { E. Achigan-Dako } 07 \text { NIA } \\
809 \text { (GAT) }\end{array}$ & Ghana, Eastern Region & HQ608240 & & HQ608327 & HQ608387 & HQ608374 & HQ608447 & HQ608164 & \\
\hline C. barteri (Hook. f.) Keay & 5 & $\begin{array}{l}\text { W. J. J. O. de Wilde et al. } \\
3736 \text { (MO) }\end{array}$ & Cameroon, Central Region & HQ608241 & & HQ608328 & HQ608388 & HQ608375 & HQ608448 & & \\
\hline C. barteri (Hook. f.) Keay & 6 & $\begin{array}{l}\text { M. A. van Bergen } 490 \\
\text { (WAG) }\end{array}$ & Gabon, Ogooué-Maritime & HQ608242 & HQ608278 & HQ608329 & HQ608406 & HQ608406 & HQ608449 & HQ608165 & \\
\hline C. barteri (Hook. f.) Keay & 7 & $\begin{array}{l}\text { F. J. Fernández-Casas } 12077 \\
\text { (MO) }\end{array}$ & Equatorial Guinea, Bioco Island & HQ608238 & HQ608279 & HQ608332 & HQ608390 & HQ608377 & HQ608453 & & \\
\hline
\end{tabular}


Table 1 Voucher information and GenBank accession numbers (Continued)

\begin{tabular}{|c|c|c|c|}
\hline C. grandiflora Cogn. & 1 & H. Schäfer 05/302 (M) & Tanzania, Tanga \\
\hline C. grandiflora Cogn. & 2 & N. Holstein et al. 98 (M) & Tanzania, Tanga \\
\hline C. grandis (L.) Voigt & 1 & $\begin{array}{l}\text { W. J. J. O. de Wilde \& B. E. } \\
\text { E. Duyfjes } 22270(\mathrm{~L})\end{array}$ & Thailand, Bangkok \\
\hline C. grandis (L.) Voigt & 2 & $\begin{array}{l}\text { R. Müller s.n., Aug. } 1999 \\
\text { (MSB) }\end{array}$ & Sudan, Sannar Prov. \\
\hline C. grandis (L.) Voigt & 3 & H. Schäfer 05/258 (M) & Tanzania, Pwani \\
\hline $\begin{array}{l}\text { C. heterophylla (Hook. f.) } \\
\text { Holstein }\end{array}$ & & $\begin{array}{l}\text { C. C. H. Jongkind } 5905 \\
\text { (WAG) }\end{array}$ & Gabon, Estuaire \\
\hline C. hirtella Cogn. & 1 & N. Holstein $29(\mathrm{M})$ & $\begin{array}{l}\text { J.-L. Gatard, France, wild source } \\
\text { unknown }\end{array}$ \\
\hline C. hirtella Cogn. & 2 & $\begin{array}{l}\text { S. S. Renner \& A. Kocyan } \\
2447 \text { (M) }\end{array}$ & $\begin{array}{l}\text { J.-L. Gatard, France, wild source } \\
\text { unknown }\end{array}$ \\
\hline C. keayana R. Fernandes & 1 & F. C. Straub 140 (BR) & Liberia \\
\hline C. keayana R. Fernandes & 2 & $\begin{array}{l}\text { C. C. H. Jongkind et al. } \\
6542 \text { (WAG) }\end{array}$ & Liberia, Grand Gedeh \\
\hline C. longicarpa Jongkind & & $\begin{array}{l}\text { C. C. H. Jongkind } 3970 \\
\text { (WAG) }\end{array}$ & Ghana, Ashanti Region \\
\hline $\begin{array}{l}\text { C. mackenii Naudin ex C. } \\
\text { Huber }\end{array}$ & & R. G. Strey 3762 (M) & South Africa, Mpumalanga \\
\hline C. megarrhiza C. Jeffrey & 1 & $\begin{array}{l}\text { J. J. F. E. de Wilde } 6501 \\
\text { (WAG) }\end{array}$ & Ethiopia, Oromia Region \\
\hline C. megarrhiza C. Jeffrey & 2 & I. Friis et al. 2664 (MO) & Ethiopia, Oromia Region \\
\hline C. megarrhiza C. Jeffrey & 3 & P. C. M. Jansen 3471 (WAG) & Ethiopia, Oromia Region \\
\hline C. megarrhiza C. Jeffrey & 4 & $\begin{array}{l}\text { J. J. F. E. de Wilde } 4793 \\
\text { (WAG) }\end{array}$ & Ethiopia, Oromia Region \\
\hline C. microphylla Gilg & 1 & $\begin{array}{l}\text { R. B. Drummond \& J. H. } \\
\text { Hemsley } 4087 \text { (B) }\end{array}$ & Kenya, Coast Province \\
\hline C. microphylla Gilg & 2 & $\begin{array}{l}\text { J. J. F. E. de Wilde \& M. G. } \\
\text { Gilbert } 346 \text { (UPS) }\end{array}$ & Ethiopia, Somali Regional State \\
\hline $\begin{array}{l}\text { C. mildbraedii Gilg ex } \\
\text { Harms }\end{array}$ & 1 & M. Reekmans 7399 (BR) & Burundi, Muramvya Prov. \\
\hline $\begin{array}{l}\text { C. mildbraedii Gilg ex } \\
\text { Harms }\end{array}$ & 2 & N. Holstein et al. 76 (M) & Tanzania, Morogoro \\
\hline C. ogadensis Thulin & & M. Thulin et al. 11183 (UPS) & Ethiopia, Somali Regional State \\
\hline $\begin{array}{l}\text { C. quinqueloba (Thunb.) } \\
\text { Cogn. }\end{array}$ & & R. D. A. Bayliss 8470 (M) & South Africa, Eastern Cape \\
\hline C. racemiflora Kéraudren & 1 & I. van Nek 536 (WAG) & Gabon, Ogooué-Maritime \\
\hline C. racemiflora Kéraudren & 2 & J. J. Bos 6590 (WAG) & Cameroon, South Prov. \\
\hline C. rehmannii Cogn. & 1 & $\begin{array}{l}\text { S. S. Renner \& A. Kocyan } \\
2749 \text { (M) }\end{array}$ & $\begin{array}{l}\text { southern Africa, no detailed } \\
\text { information }\end{array}$ \\
\hline
\end{tabular}

$\begin{array}{llllllll}\text { HQ608243 } & \text { HQ608280 } & \text { HQ608333 } & \text { HQ608407 } & \text { HQ608407 } & \text { HQ608454 } & \text { HQ608166 } & \text { HQ608205 } \\ \text { HQ608244 } & \text { HQ608281 } & \text { HQ608334 } & \text { HQ608408 } & \text { HQ608408 } & \text { HQ608455 } & \text { HQ608167 } & \end{array}$

DQ536651 HQ608282 DQ536537 DQ536762 DQ536762 HQ608456 HQ608168 HQ608207

HQ608335 HQ608409 HQ608409 HQ608457 HQ608169

HQ608245 HQ608283 HQ608336 HQ608410 HQ608410 HQ608458 HQ608170 HQ608206

HQ608246 HQ608337 HQ608411 HQ608411 HQ608459 HQ608171

HQ608247 HQ608284 HQ608339 HQ608412 HQ608412 HQ608461 HQ608172

HQ608248 HQ608338 HQ608413 HQ608413 HQ608460

$\begin{array}{llllll} & \text { HQ608462 } & & \\ \text { HQ608249 HQ608285 HQ608340 } & \text { HQ608378 } & \text { HQ608463 HQ608173 HQ608211 }\end{array}$

HQ608250 HQ608286 HQ608341 HQ608414 HQ608414 HQ608464 HQ608174 HQ608212

HQ608251 HQ608343 HQ608415 HQ608415 HQ608465

HQ608344 HQ608417 HQ608417 HQ608466

HQ608252 HQ608287 HQ608347 HQ608416 HQ608416 HQ608469 HQ608176

$\begin{array}{llll} & \text { HQ608345 } & \text { HQ608467 } & \\ \text { HQ608253 } & \text { HQ608346 } & \text { HQ608468 } & \text { HQ608175 }\end{array}$

$\begin{array}{lll}\text { HQ608254 HQ608348 HQ608470 HQ608177 } & \end{array}$

HQ608255 HQ608349 HQ608418 HQ608418 HQ608471 HQ608178 HQ608213

$\begin{array}{lll}\text { HQ608256 HQ608350 HQ608472 } & \end{array}$

HQ608257 HQ608288 HQ608351 HQ608419 HQ608419 HQ608473 HQ608179

$\begin{array}{llll}\text { HQ608258 HQ608289 HQ608352 HQ608474 HQ608214 } & \end{array}$

HQ608259 HQ608290 HQ608353 HQ608420 HQ608420 HQ608475 HQ608180

$\begin{array}{lllllll} & \text { HQ608355 } & \text { HQ608421 } & \text { HQ608421 } & \text { HQ608477 } & \text { HQ608182 } & \text { HQ608217 } \\ \text { HQ608260 } & \text { HQ608354 } & \text { HQ608391 } & \text { HQ608379 } & \text { HQ608476 } & \text { HQ608181 } & \end{array}$

DQ536652 HQ608292 HQ625508 DQ536799 DQ536799 HQ608479 HQ608184 HQ608218 
Table 1 Voucher information and GenBank accession numbers (Continued)

\begin{tabular}{|c|c|c|c|c|c|c|c|c|c|c|c|}
\hline $\begin{array}{l}\text { C. rehmannii Cogn. var. } \\
\text { littoralis A. Meeuse }\end{array}$ & 2 & L. E. Codd 9620 (M) & South Africa, KwaZulu-Natal & HQ608261 & & HQ625509 & HQ608422 & HQ608422 & HQ608480 & & \\
\hline $\begin{array}{l}\text { C. rehmannii Cogn. var. } \\
\text { rehmannii }\end{array}$ & 3 & G. Woortman 217 (M) & Namibia, Otjozondjupa & HQ608262 & & HQ625510 & HQ608392 & HQ608380 & HQ608481 & HQ608185 & \\
\hline C. rehmannii Cogn."ovifera" & 4 & $\begin{array}{l}\text { B. de Winter \& O. A. Leistner } \\
5598(\mathrm{M})\end{array}$ & Namibia, Kunene & HQ608263 & HQ608291 & HQ608356 & HQ608423 & HQ608423 & HQ608478 & HQ608183 & \\
\hline C. samburuensis Holstein & & $\begin{array}{l}\text { R. B. \& A. J. Faden 74/948 } \\
\text { (WAG) }\end{array}$ & Kenya, Rift Valley Prov. & HQ608264 & HQ608293 & HQ608357 & HQ608393 & HQ608381 & HQ608482 & HQ608186 & \\
\hline C. schliebenii Harms & 1 & $\begin{array}{l}\text { E. Westphal \& J. M. C. } \\
\text { Westphal-Stevels } 5539 \\
\text { (WAG) }\end{array}$ & Ethiopia, Oromia Region & & HQ608294 & HQ608358 & & & HQ608483 & & \\
\hline C. schliebenii Harms & 2 & G. S. Laizer et al. $1449(\mathrm{MO})$ & Tanzania, Morogoro & HQ608265 & & HQ608359 & & HQ608382 & HQ608484 & HQ608187 & \\
\hline C. senensis (Klotzsch) Cogn. & 1 & N. Holstein et al. 66 (M) & Tanzania, Morogoro & HQ608266 & HQ608295 & HQ608360 & HQ608424 & HQ608424 & HQ608485 & HQ608188 & \\
\hline C. senensis (Klotzsch) Cogn. & 2 & K. Vollesen MRC4316 (WAG) & Tanzania, Lindi & HQ608267 & HQ608296 & HQ608362 & HQ608425 & HQ608425 & HQ608487 & HQ608189 & HQ608219 \\
\hline C. senensis (Klotzsch) Cogn. & 3 & $\begin{array}{l}\text { A. R. Torre et al. } 18788 \\
\text { (MO) }\end{array}$ & Mozambique, Tete & & & HQ608361 & & & HQ608486 & & \\
\hline C. senensis (Klotzsch) Cogn. & 4 & $\begin{array}{l}\text { E. M. C. Groenendijk et al. } \\
1031 \text { (WAG) }\end{array}$ & Mozambique, Nampula & & & HQ625511 & & & HQ608489 & & \\
\hline C. senensis (Klotzsch) Cogn. & 5 & J. Lovett $1597(\mathrm{MO})$ & Tanzania, Iringa & HQ608233 & & HQ608323 & HQ608386 & HQ608372 & HQ608441 & & \\
\hline C. senensis (Klotzsch) Cogn & 6 & C. F. Paget-Wilkes 72 (MO) & Tanzania, Iringa & HQ608234 & & HQ608324 & & HQ608373 & HQ608442 & & \\
\hline C. sessilifolia (Sond.) Cogn. & & S. S. Renner et al. 2763 (M) & $\begin{array}{l}\text { Plant grown at Mainz Bot. G. } \\
\text { (MJG19-54430); wild source } \\
\text { unknown }\end{array}$ & AY968446 & HQ608297 & DQ648163 & AY968568 & AY968385 & HQ608490 & HQ608190 & HQ608220 \\
\hline C. spec. nov. & & $\begin{array}{l}\text { C. Geerling \& J. Bokdam } \\
662(\mathrm{MO})\end{array}$ & Ivory Coast, Bouna area & HQ608269 & HQ608298 & HQ608363 & & HQ608383 & HQ608491 & & \\
\hline C. subsessiliflora Cogn. & & H. F. in de Witte 8288 (M) & DR Congo, Kivu & HQ608270 & & HQ608365 & HQ608395 & HQ608384 & HQ608493 & & \\
\hline $\begin{array}{l}\text { C. trilobata (Cogn.) C. } \\
\text { Jeffrey }\end{array}$ & & $\begin{array}{l}\text { N. Holstein \& P. Sebastian } 9 \\
\text { (M) }\end{array}$ & J.-L. Gatard, France, coll. in Kenya & HQ608271 & HQ608300 & HQ608366 & HQ608426 & HQ608426 & HQ608494 & & HQ608222 \\
\hline $\begin{array}{l}\text { Diplocyclos palmatus (L.) C. } \\
\text { Jeffrey }\end{array}$ & & J. Maxwell s.n. 2 Sep. 2002 & Thailand, Chiang Mai & DQ536671 & HQ608301 & DQ536625 & DQ536769 & DQ536769 & HQ608495 & HQ608192 & \\
\hline $\begin{array}{l}\text { Diplocyclos schliebenii } \\
\text { (Harms) C. Jeffrey }\end{array}$ & & H. J. Schlieben 4363 (M) & Tanzania, Kilimanjaro & & & & HQ608427 & HQ608427 & HQ608496 & HQ608193 & HQ608223 \\
\hline Cucumis hirsutus Sond. & & N. B. Zimba et al. 874 (MO) & Zambia & DQ536658 & & DQ536542 & DQ536804 & DQ536804 & HM597074 & & \\
\hline Cucumis sativus $\mathrm{L}$. & & Unknown & unknown & AJ970307 & AJ970307 & AJ970307 & AJ970307 & AJ970307 & AJ970307 & & \\
\hline $\begin{array}{l}\text { Peponium vogelii (Hook. f.) } \\
\text { Engl. }\end{array}$ & & S. S. Renner 2710 (M) & Tanzania, Tanga & HQ608272 & HQ608302 & HQ608367 & HQ608428 & HQ608428 & HQ608497 & HQ608194 & \\
\hline $\begin{array}{l}\text { Scopellaria marginata (BI.) } \\
\text { W. de Wilde and Duyfjes }\end{array}$ & & A. Kocyan AK178 (BKF) & Thailand & DQ536751 & & DQ536612 & DQ536804 & DQ536804 & & & \\
\hline
\end{tabular}




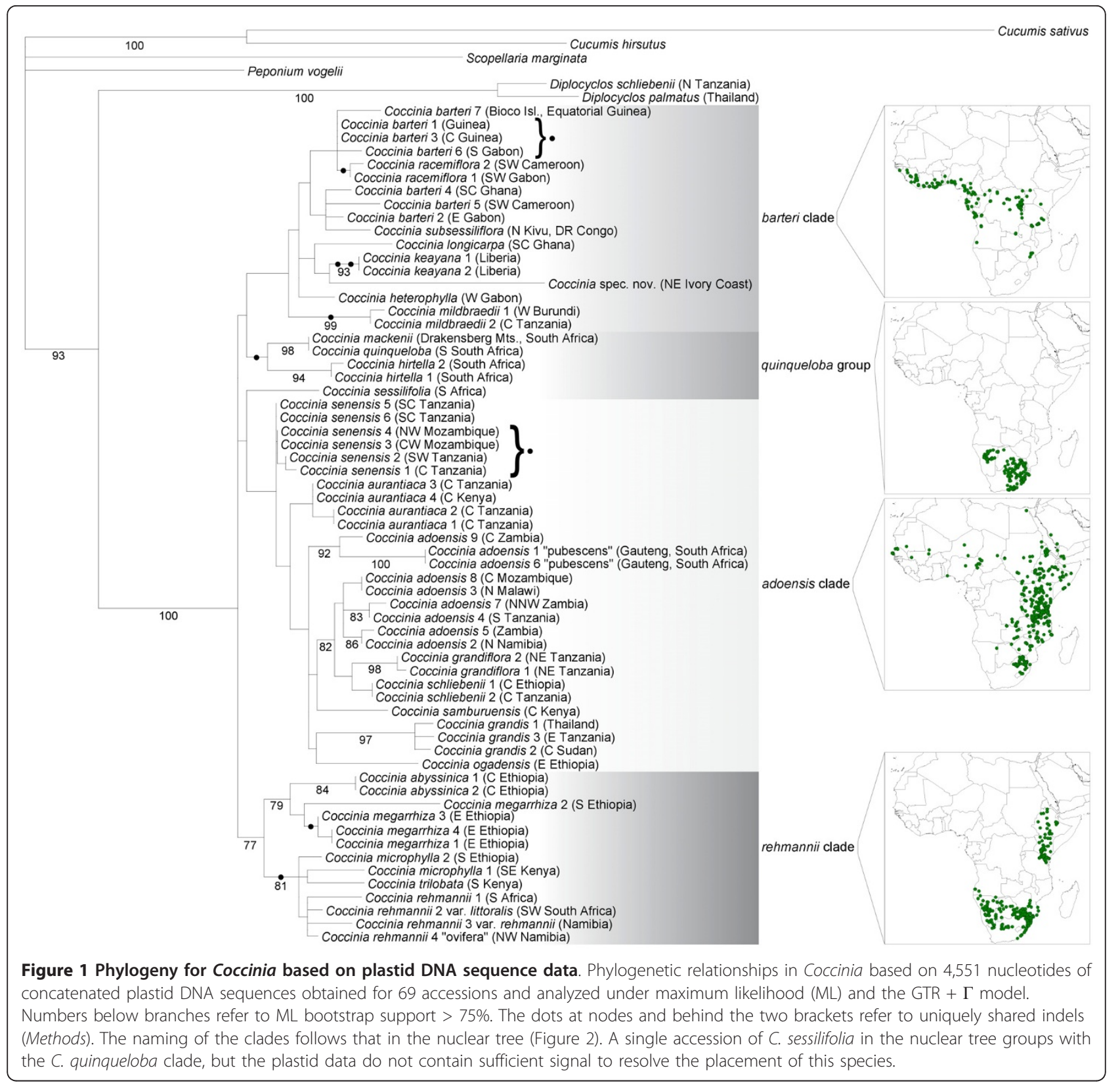

shifts on the phylogeny and the Mann-Whitney U tests revealed at least six habitat changes (marked by red arrows in Figure 4b), counting only changes in statistically supported sister species or clades. Differentiation of precipitation preferences within habitat category (e.g., in C. quinqueloba versus C. mackenii, Table 2a) was not counted as a biome shift.

We next tested whether the number of pairs of species that have the same niche preferences differs from that obtained if species habitat distributions were drawn at random (proportion 0.635 ). Among the 27 nodes in the phylogeny, 6 involved habitat shifts (red arrows in Figure 4), which is significantly fewer than the expected number of $17(G=9.4, \mathrm{df}=1, P=0.0021)$. Even when the four most basal nodes are deleted from the analysis owing to the ambiguity of their character states, the phylogeny still includes significantly fewer habitat shifts than expected at random $(G=6.5, \mathrm{df}=1, P=0.011)$. Thus, occupation of one of our three habitat categories appears to be a statistically conservative trait in the sense that daughter lineages tend to retain habitat type more frequently than expected by chance, given that the random probabilities are estimated from the current distributions of species. The next sections briefly describe the geography and timing of the inferred six shifts between semi-arid habitats, woodland, and forest. 


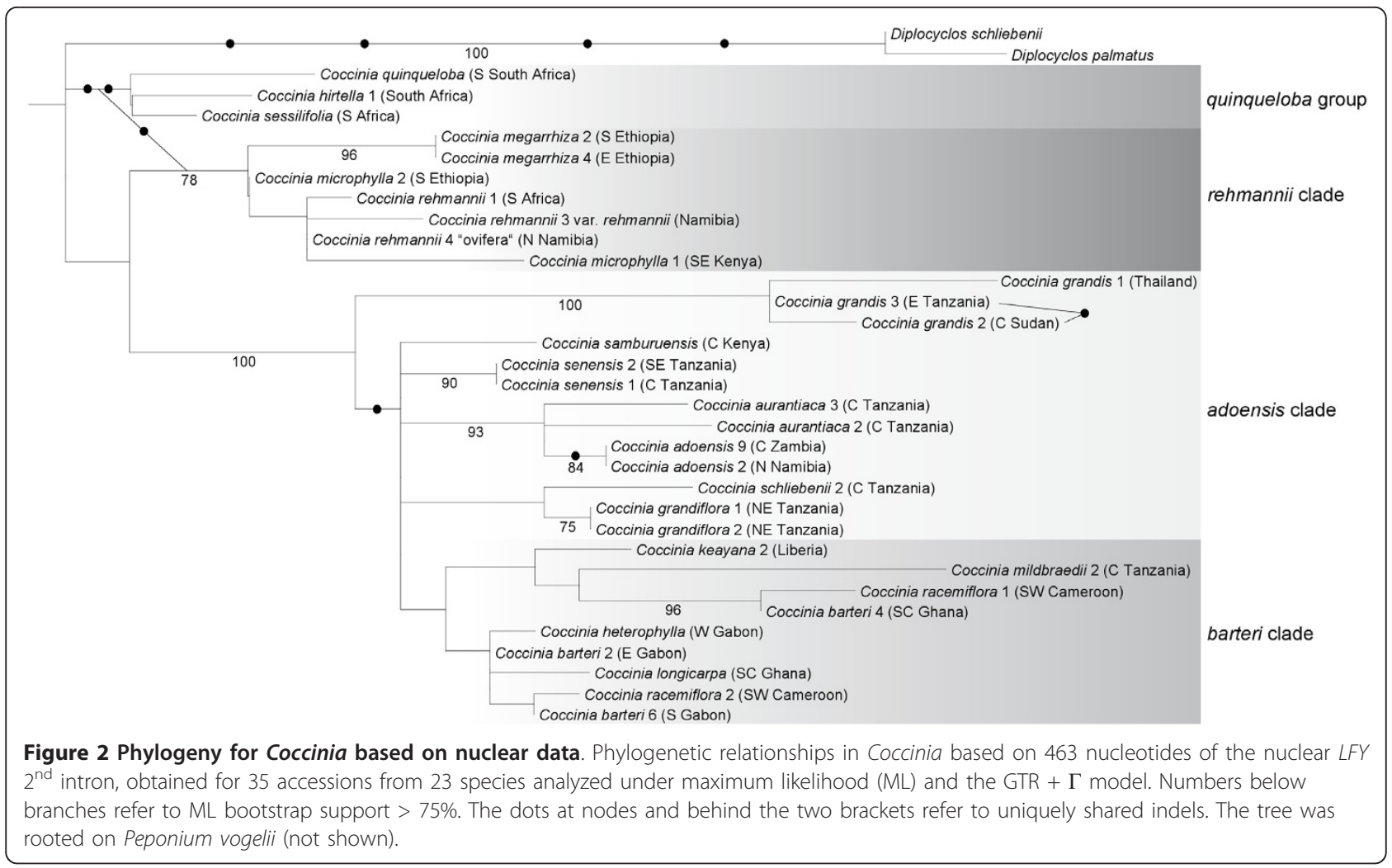

The Coccinia quinqueloba group comprises four species and began diversifying c. 5 Ma (7.5 - 2.4 95\% HPD) ago. Its divergence times and habitat preferences are shown in Figure 4, geographic ranges in Figure 5b, and precipitation tolerances in Figure 6. The species in this group occur in two habitat categories (forest and semiarid habitat), and there was at least one niche shift in terms of the tolerated precipitation regime. The three forest species (of which C. mackenii and C. quinqueloba have identical sequences in 3503 nucleotides) diverged around $2.8 \mathrm{Ma}$ (4.7 - 1.1 95\% HPD) ago, during the Late Pliocene to Pleistocene.

The Coccinia barteri clade includes eight Central and West African species plus the East African (Tanzanian)

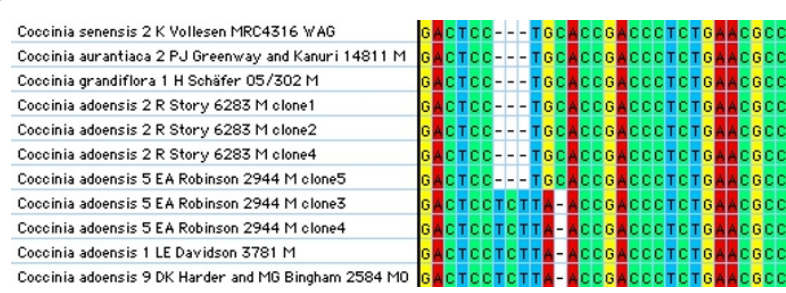

Figure 3 Detail of the nuclear ITS alignment for Coccinia. Section of the aligned Coccinia nuclear internal transcribed spacer (ITS) sequences, indicating gene flow between individuals of $C$. adoensis with different plastid genotypes.
C. mildbraedii (incl. C. ulugurensis); Figure 5a shows the species' geographic ranges (except for Coccinia spec. nov.; Table 1 provides the vouchers and code numbers for each sequenced plant) and Figure 6 their climatic tolerances. Diversification of this clade began $5 \mathrm{Ma}$ (7.6 - 2.7 95\% HPD; Figure 4a) ago, that is, at the beginning of the Early Pliocene warming. Most of the species occur in lowland rain forests or mountain forests at elevations up to $2900 \mathrm{~m}$, although C. barteri and C. heterophylla also have been collected in humid semideciduous forests and clearings. Coccinia spec. nov. represents a biome shift from rain forest to semi-humid savanna (our woodland category). Coccinia barteri is morphologically diverse, and based on herbarium material, species boundaries in the barteri clade tend to be cryptic (Table 3 ).

The Coccinia adoensis clade comprises nine species and includes at least two biome shifts (Figure $4 \mathrm{~b}$ ). The first involves the sister species C. grandiflora and C. schliebenii, which occur in (rain-) forests of East Africa (Figures $4 \mathrm{~b}$ and 7), while their widespread relative C. adoensis occurs in mountain grasslands, deciduous woodlands, and rarely in moister bushlands (> $450 \mathrm{~mm}$ annual precipitation, $<7$ months of aridity) from South Africa to Ethiopia and to Nigeria. The deeper split is dated to the Late Pleistocene (c. 2.1 Ma ago), while C. grandiflora/C. schliebenii separated from each other 


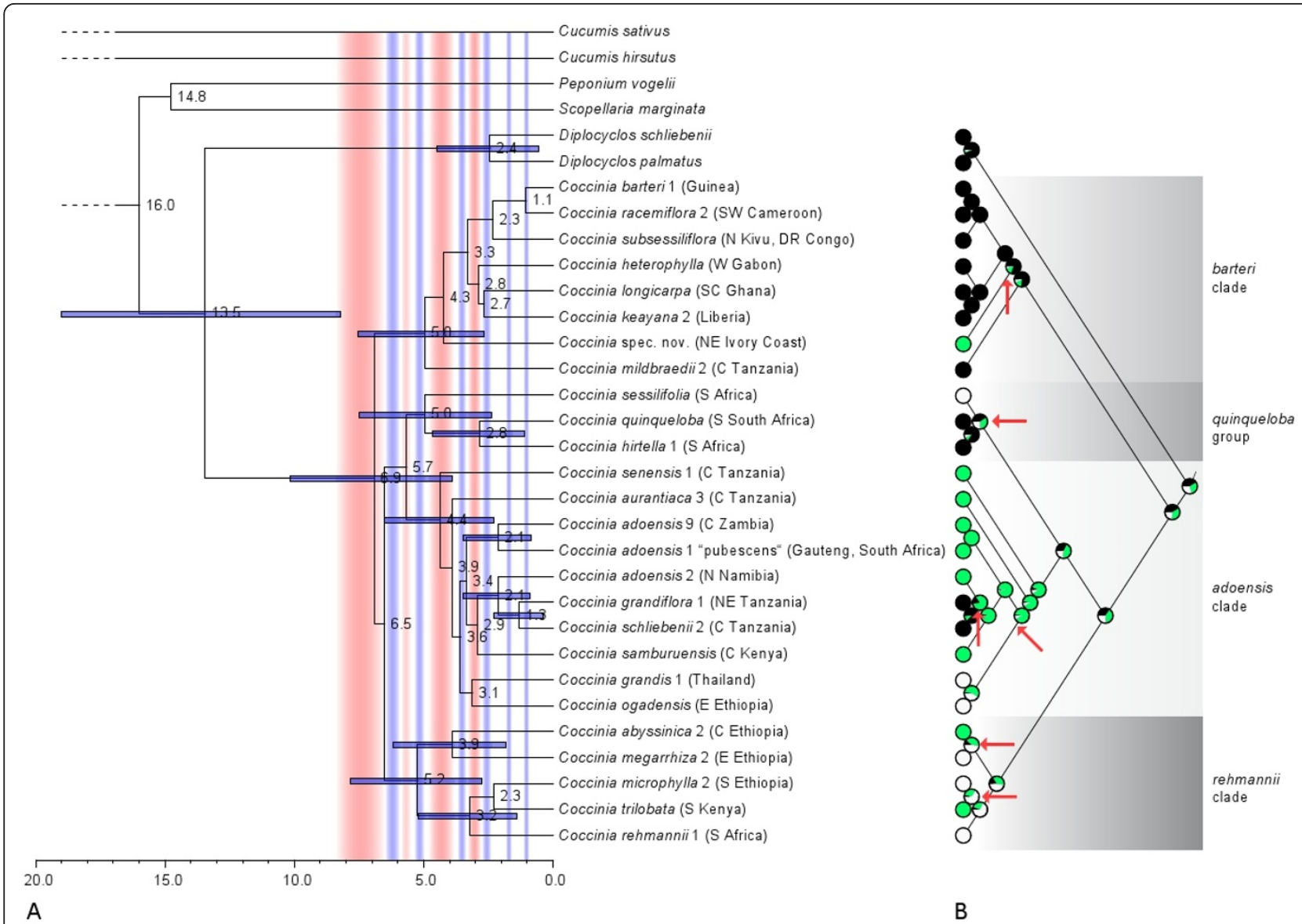

Figure 4 Chronogram and ancestral character reconstruction in Coccinia. a. Chronogram for 24 Coccinia species (C. mackenii and C. quinqueloba had identical sequences, and the former was therefore removed; Methods) obtained under a Bayesian strict clock model. Clades are labeled as in Figure 1 and 2; blue bars around mean node ages represent the 95\% highest posterior density credibility interval, and are given for all nodes with $\geq 0.98$ posterior probability. Pale red backgrounds indicates warm (humid) climate, pale blue backgrounds, cold (arid) climates after [15]. b. Ancestral biome reconstruction on the Bayesian tree obtained from the plastid DNA data for Coccinia; Black = forest, green $=$ woodland and semi-humid savannas, and white $=$ semi-arid habitats. Red arrows indicate biome shifts.

c. 1.3 Ma ago (Figure 4a). The second biome shift involves C. ogadensis and C. grandis, which are adapted to semi-arid conditions (Figure 4b).

The Coccinia rehmannii clade, which started diversifying during an arid period at the end of the Miocene 5.2 Ma (7.9 - 2.8 95\% HPD) ago (Figure 4a), comprises five species (Figure 7: blue dots) and two biome switches (Figure $4 \mathrm{~b}$ ). The split between $C$. abyssinica and C. megarrhiza dates to c. 3.9 Ma ago, at the end of the warm and humid Early Pliocene, and that of C. rehmannii from C. microphylla and C. trilobata to c. $3.2 \mathrm{Ma}$, during the humid Late Pliocene. The climate tolerances of the five species are shown in Figure 6.

\section{Evidence for Hybridization}

One of the incongruities between the nuclear and plastid DNA tree topologies concerns C. racemiflora from rain forests of west equatorial Africa. In the plastid tree
(Figure 1), C. racemiflora 1 and C. racemiflora 2 group together and share a $490 \mathrm{bp}$ deletion in $\operatorname{trn} \mathrm{S}^{\mathrm{GCU}}$ trn $\mathrm{G}^{\mathrm{UCC}}$ intergenic spacer. Morphologically, these two plants appear to represent the same species. However, in the nuclear $L F Y$ tree (Figures 2), C. racemiflora 1 groups with $C$. barteri 4 while $C$. racemiflora 2 groups with $C$. barteri 6 . The latter plant is morphologically intermediate between $C$. barteri and C. racemiflora and may present a hybrid.

Two other incongruities concern C. adoensis (compare accessions 1 to 9 in Figure 1-3). First, in the plastid tree (Figure 1), C. adoensis accessions from East Africa cluster with the East African C. grandiflora and C. schliebenii, while pubescent $C$. adoensis accessions 1 and 6 from South Africa (originally described as C. pubescens) cluster with a glabrous $C$. adoensis 9 from southern Zambia. In the nuclear $L F Y$ tree (Figure 2), C. adoensis 2, which in the plastid tree clustered with East African plants, 
Table 2 Pairwise Mann-Whitney $U$ tests among species of supported clades in the Coccinia phylogeny

a. Pairwise Mann-Whitney $U$ tests among species of the Coccinia rehmannii clade and the C. quinqueloba group

\begin{tabular}{|c|c|c|c|c|c|c|c|c|c|c|}
\hline & abyssinica & megarrhiza & microphylla & trilobata & rehmannii & quinqueloba & mackenii & hirtella & sessilifolia & \\
\hline abyssinica & - & $0.047^{*}$ & & & & & & & & \\
\hline megarrhiza & $<0.001 * *$ & - & & & & & & & & \\
\hline microphylla & & & - & $<0.001^{* *}$ & 0.971 & & & & & \\
\hline trilobata & & & $<0.001^{* *}$ & - & $<0.001^{* *}$ & & & & & \\
\hline rehmannii & & & 0.128 & $<0.001^{* *}$ & - & & & & & \\
\hline quinqueloba & & & & & & - & $0.004^{*}$ & $0.013^{*}$ & $<0.001^{* *}$ & \\
\hline mackenii & & & & & & $<0.001^{* *}$ & - & 0.206 & $<0.001^{* *}$ & \\
\hline hirtella & & & & & & $<0.001^{* *}$ & $0.003^{*}$ & - & $<0.001^{* *}$ & \\
\hline sessilifolia & & & & & & $<0.001^{* *}$ & $<0.001^{* *}$ & $<0.001^{* *}$ & - & \\
\hline \multicolumn{11}{|c|}{ b. Pairwise Mann-Whitney U tests among species of the Coccinia barteri clade } \\
\hline & barteri & racemiflora & subsessiliflora & longicarpa & keayana & heterophylla & spec. nov. & mildbraedii & & \\
\hline barteri & - & 0.336 & $0.001^{*}$ & 0.087 & 0.056 & $0.001 *$ & $0.006^{*}$ & 0.335 & & \\
\hline racemiflora & $0.009^{*}$ & - & $0.026^{*}$ & 0.094 & 0.091 & 0.445 & 0.095 & 0.601 & & \\
\hline subsessiliflora & 0.63 & $<0.001^{* *}$ & - & $0.027^{*}$ & 0.077 & $<0.001^{* *}$ & $0.017^{*}$ & $0.045^{*}$ & & \\
\hline longicarpa & 0.771 & $<0.001^{* *}$ & 0.251 & - & 0.746 & $<0.001^{* *}$ & $0.011^{*}$ & 0.94 & & \\
\hline keayana & $0.009^{*}$ & 0.968 & $0.002^{*}$ & $0.012^{*}$ & - & $<0.001^{* *}$ & $0.026^{*}$ & 0.871 & & \\
\hline heterophylla & $0.016^{*}$ & $0.042^{*}$ & $0.041^{*}$ & $0.018^{*}$ & $0.002^{*}$ & - & $0.029^{*}$ & $0.006^{*}$ & & \\
\hline spec. nov. & 0.093 & 0.095 & $0.017^{*}$ & $0.042^{*}$ & $0.013^{*}$ & 0.941 & - & $0.003^{*}$ & & \\
\hline mildbraedii & $0.004^{*}$ & $<0.001^{* *}$ & $0.036^{*}$ & $0.002^{*}$ & $<0.001^{* *}$ & 0.148 & 0.139 & - & & \\
\hline \multicolumn{11}{|c|}{ c. Pairwise Mann-Whitney U tests among species of the Coccinia adoensis clade } \\
\hline & senensis & aurantiaca & adoensis 9 & adoensis "pubescens" & adoensis & grandiflora & schliebenii & samburuensis & ogadensis & grandis \\
\hline senensis & - & 0.241 & 0.333 & $<0.001^{* *}$ & 0.549 & $<0.001^{* *}$ & $<0.001^{* *}$ & 0.333 & $<0.001^{* *}$ & 0.531 \\
\hline aurantiaca & $0.001^{*}$ & - & 0.625 & $<0.001^{* *}$ & 0.1 & $<0.001^{* *}$ & $<0.001^{* *}$ & 0.961 & $<0.001^{* *}$ & 0.35 \\
\hline adoensis 9 & 0.444 & 0.75 & - & $0.03^{*}$ & 0.281 & $0.043^{*}$ & 0.071 & 0.4 & 0.222 & 0.705 \\
\hline adoensis "pubescens" & $<0.001^{* *}$ & 0.352 & 0.636 & - & $<0.001^{* *}$ & $0.001 *$ & 0.15 & $<0.001^{* *}$ & $<0.001^{* *}$ & 0.091 \\
\hline adoensis & 0.098 & $0.01^{*}$ & 0.607 & $<0.001^{* *}$ & - & $<0.001^{* *}$ & $<0.001^{* *}$ & 0.24 & $<0.001^{* *}$ & 0.903 \\
\hline grandiflora & $0.015^{*}$ & $<0.001^{* *}$ & $0.043^{*}$ & $<0.001^{* *}$ & $<0.001 * *$ & - & 0.138 & $<0.001^{* *}$ & $<0.001^{* *}$ & $<0.001^{* *}$ \\
\hline schliebenii & $<0.001^{* *}$ & $<0.001^{* *}$ & 0.071 & $<0.001^{* *}$ & $<0.001^{* *}$ & $0.014^{*}$ & - & $0.002^{*}$ & $<0.001^{* *}$ & 0.061 \\
\hline samburuensis & $0.002^{*}$ & 0.185 & 0.4 & 0.061 & $0.006^{*}$ & $<0.001 * *$ & $<0.001^{* *}$ & - & $0.004^{*}$ & 0.521 \\
\hline ogadensis & $<0.001^{* *}$ & $<0.001^{* *}$ & 0.222 & $<0.001^{* *}$ & $<0.001^{* *}$ & $<0.001^{* *}$ & $<0.001^{* *}$ & $0.004^{*}$ & - & $0.002^{*}$ \\
\hline grandis & $0.02^{*}$ & 0.542 & 0.914 & 0.219 & $0.03^{*}$ & $<0.001^{* *}$ & $<0.001^{* *}$ & 0.314 & $<0.001 * *$ & \\
\hline
\end{tabular}

Fields above the em dash (-) line are comparisons of the number of arid months, below are comparisons of the annual precipitation. One asterisk (*) indicates significance at the $5 \%$ level, two asterisks (**) indicate significance at the $0.1 \%$ level. Bold numbers indicate statistically significant differentiation between species (biome switch). 


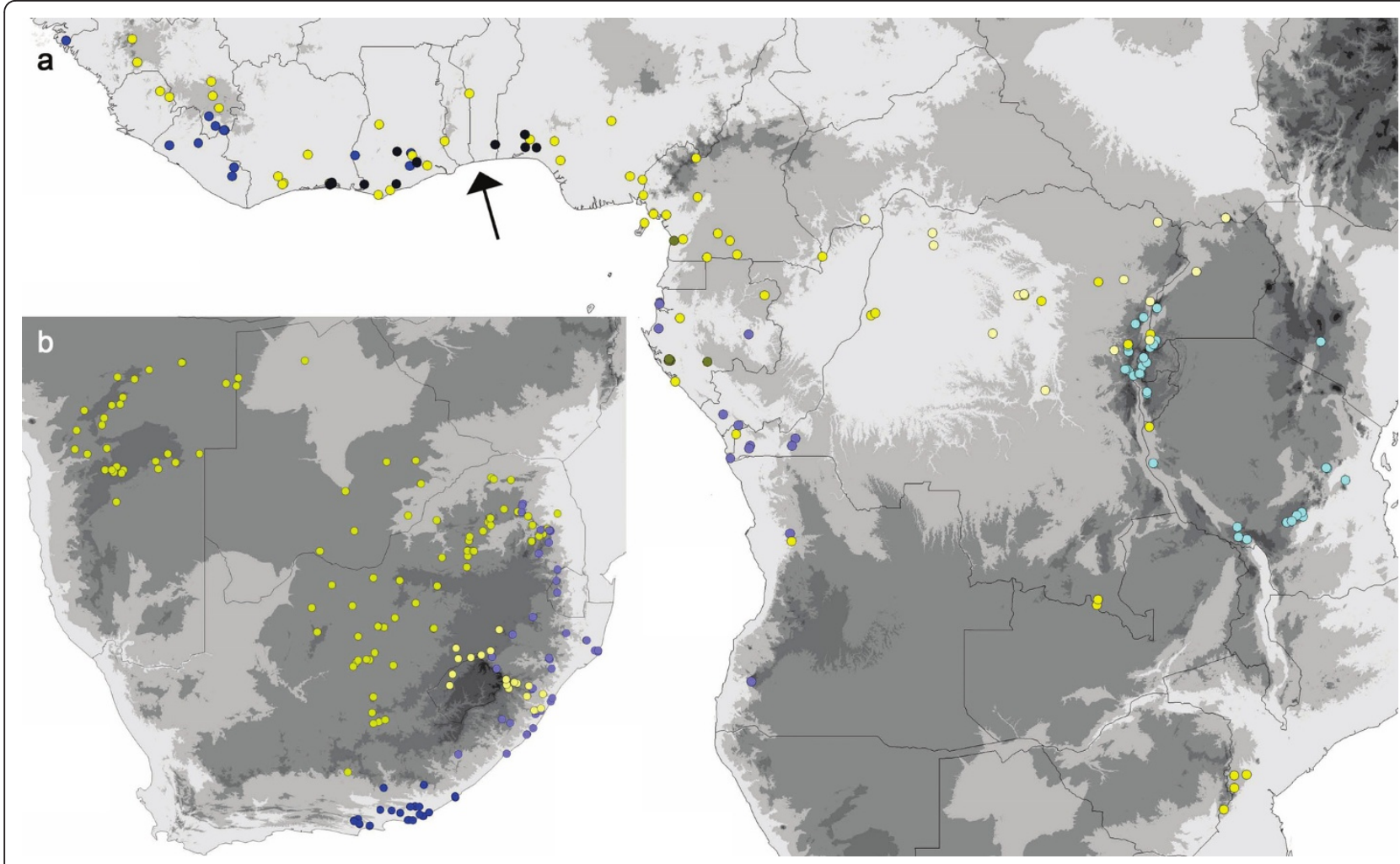

Figure 5 Distribution of species in the Coccinia barteri clade and the C. quinqueloba clade. a Distribution of species in the Coccinia barteri clade. Dark blue $=C$. Iongicarpa, deep blue $=C$. keayana, pale blue $=C$. heterophylla, light blue $=C$. mildbraedii, bright yellow $=C$. barteri morphs, dark yellow $=C$. racemiflora, pale yellow $=C$. subsessiliflora. The arrow marks the Dahomey Gap. $b$ Distribution of species in the quinqueloba group. Dark blue $=$ C. quinqueloba, pale blue $=$ C. mackenii, bright yellow $=$ C. sessilifolia, pale yellow $=$ C. hirtella .

instead groups with $C$. adoensis 9 (South African C. adoensis plants did not yield $L F Y$ sequences). The ITS alignment (Figure 3) reveals that single individuals of $C$. adoensis can have two kinds of sequences: C. adoensis 5 from Zambia (sister to adoensis 2 in the plastid DNA data; Figure 1) harbors sequences matching C. adoensis 1 from South Africa as well as sequences matching C. adoensis 2 from Namibia. Second, in the plastid tree, East African C. adoensis are distant from C. aurantiaca, while in the nuclear tree they are in a polytomy with C. aurantiaca and C. adoensis 9 .

\section{Discussion}

At the outset of this study, we expected minimally two biome shifts, this being the number required to explain the presence of Coccinia in semi-arid habitats, woodland, and forest. Instead, we found six statistically significant biome shifts among close relatives (marked in Figure $4 \mathrm{~b}$ ). However, this is still fewer than if the habitats were distributed on the phylogeny at random. The onset of Coccinia diversification dates to just $6.9 \mathrm{Ma}$ ago, a time when the warm and humid climate began to become cooler and drier. Climatic conditions then continued to oscillate during the Pliocene and Quaternary
(Background). Additionally, the East African rifting led to aridification and more open grasslands starting at 7 $8 \mathrm{Ma}$ ago [15], [19]. Depending on species' ecological tolerances, these climate fluctuations must have caused range reduction and fragmentation, or expansion and merging. The likely ancestral precipitation preferences of the Coccinia clade remain unresolved (Figure 4b); the sister genus, Diplocyclos, which comprises four species, is restricted to rain forest and semi-deciduous woodlands [31].

The 12 forest species of Coccinia all have discontinuous distributional ranges, as exemplified by C. grandiflora (Figure 7), fitting with forest expansion during Pleistocene interglacials that likely reconnected most forest refugia [33]. Survival in persisting refugia probably explains the populations of C. subsessiliflora in the southern Sudanese Imatong Mts. (Figure 5a), of C. barteri in the mountain region between Zimbabwe and Mozambique, and of C. mildbraedii in the Eastern Arc Mts. For C. heterophylla, which occurs in the Angola Escarpment at $15^{\circ} 30^{\prime} \mathrm{S}$ (Figure 5a), mist-saturated local vegetation pockets [34] may have offered survival possibilities during dry periods, while the presence of C. mildbraedii in the Kenyan highlands (Figure 5a), may 


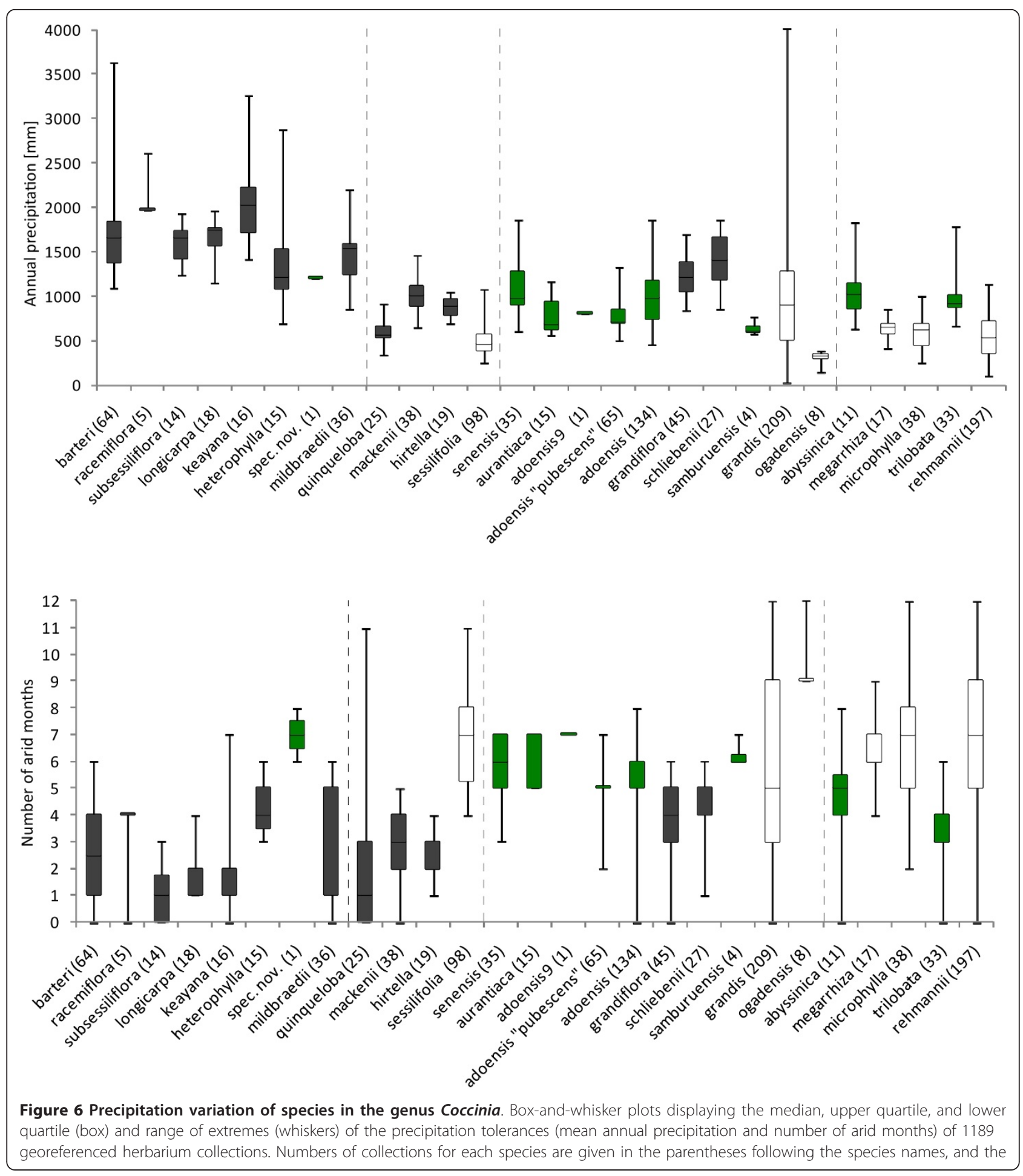

result from introduction by humans (fide label information on the specimen J. B. Gillett 20185, MO, NHT). It nevertheless shows that Central African species would probably find suitable habitats in East Africa if forest expansion advanced further.
The Coccinia barteri clade is interesting in containing two rain forest species (C. longicarpa and C. keayana) with overlapping distributions (Figure 5a) and co-occurrence in the same habitats (e.g., in the Banco Forest Reserve, Abidjan, Ivory Coast). They likely descend from a widespread 
Table 3 Key characters among forest species in the Coccinia barteri clade, illustrating the high level of morphological differentiation among close relatives (Figure 1 and 2)

\begin{tabular}{|c|c|c|c|c|c|}
\hline $\begin{array}{l}\text { Species / } \\
\text { accession }\end{array}$ & $\begin{array}{l}\text { Male raceme } \\
\text { morphology }\end{array}$ & Bracts & Calyx teeth & $\begin{array}{l}\text { Fruit } \\
\text { shape }\end{array}$ & Other characters \\
\hline C. mildbraedii & Condensed on long stalk & No & Upright, short, acute & $\begin{array}{l}\text { Long } \\
\text { cylindrical }\end{array}$ & Tendrils bifid \\
\hline C. keayana & Lax, many-flowered & No & Erect-reflexed, long, narrow & Ovoid & Tendrils simple \\
\hline C. longicarpa & Condensed & No & Erect-upright, broad & $\begin{array}{l}\text { Long } \\
\text { cylindrical }\end{array}$ & Tendrils simple (rarely bifid) \\
\hline C. heterophylla & $\begin{array}{l}\text { Condensed (rarely also } \\
\text { lax) }\end{array}$ & Yes & Upright, long subulate & Ovoid & Tendrils bifid \\
\hline C. subsessiliflora & Condensed, few-flowered & Yes & Upright, short, acute & Ovoid & $\begin{array}{l}\text { Tendrils simple; leaves more deeply lobate } \\
\text { than in other species }\end{array}$ \\
\hline C. racemiflora & Lax, many-flowered & No & $\begin{array}{l}\text { Erect-upright, slightly fleshy, } \\
\text { short, narrow }\end{array}$ & Ovoid & Tendrils bifid \\
\hline $\begin{array}{l}\text { C. barteri (type } \\
\text { morph) }\end{array}$ & $\begin{array}{l}\text { Condensed, many- } \\
\text { flowered }\end{array}$ & Yes & Upright, short, acute & Ovoid & Tendrils simple or bifid \\
\hline C. barteri 7-like & Condensed & Yes & Reflexed, fleshy, short & Ovoid & Tendrils simple or bifid \\
\hline C. barteri 2 & Condensed, few-flowered & No & Erect-reflexed, short, subulate & Ovoid & Tendrils bifid \\
\hline C. barteri 4 & Condensed, few-flowered & Yes & Upright, short, acute & $?$ & Tendrils simple or bifid \\
\hline C. barteri 5 & Condensed, few-flowered & No & Erect, short, acute & $?$ & Tendrils simple \\
\hline $\begin{array}{l}\text { C. barteri } 6 \\
\text { (xracemiflora?) }\end{array}$ & $\begin{array}{l}\text { Condensed, but pedicels } \\
\text { rather long }\end{array}$ & No & Upright, short, acute & $?$ & Tendrils bifid \\
\hline
\end{tabular}

ancestral species, the range of which became fragmented during the cool/dry mid-Pliocene, with C. longicarpa becoming restricted to southwestern Ghana and C. keayana to Liberia, fitting with Maley's [25] refugia. Today, C. longicarpa is also distributed east of the Dahomey Gap (arrow in Figure 5), an abrupt climatically induced rain forest disjunction in West Africa. Although forest fragmentation during glacial periods likely was severe, present range disruptions in Central and West Africa seem to date only to the recent Holocene [35]. Recurrent fragmentation and reconnection of populations during the Pleistocene apparently led to hybridization and introgression, which would explain the high morphological and genetic variability in $C$. barteri (Figure 1, Table 3).

Among the few species of Coccinia that appear to have originated during and since the Pleistocene are the forest species C. grandiflora/C. schliebenii from East Africa and C. quinqueloba/C. mackenii (the latter identical in the markers sequenced here) from South Africa. Each pair comprises morphologically similar species with partly overlapping ranges (Figure 5 and 7 ). The stronger aridity in East and southern Africa compared to Central and West Africa seems to have led to Pleistocene allopatric speciation in these aridity intolerant species. That the range of C. schliebenii extends into Ethiopia and the Didinga Mts. in southeastern Sudan (Figure 7), which have similar amounts of precipitation, probably reflects long-distance seed dispersal by birds $[36,37]$, rather than remnant populations from a once continuous range. This is because intervening forests, such as those of the Usambara Mts. and Mt. Kenya, have been well collected, yet have not yielded C. schliebenii.

Coccinia species of the rehmannii clade and other dryadapted species occur on either side of the Miombo belt (with $3-6$ months of aridity), but are absent from the belt itself (Figure 7). The reason does not appear to be the belt's poor lateritic soils [38] since Coccinia species can grow on such soils (C. microphylla: R. Wingfield 1351 and 2893, DSM; C. trilobata: R. Polhill \&S. Paulo 962, K), and so are C. grandis (E. Westphal \& J. M. C. Westphal-Stevels 1385, MO, WAG; J. J. Lavranos \&S. Carter 23258, MO) and C. sessilifolia (G. Germishuizen 9384, MO; S. E. Chadwick 280, MO). Fire is an unlikely explanation too, since Coccinia species have tubers and can re-sprout. During the Pleistocene, the Miombo belt apparently was crossable for ostriches and antelopes $[39,40]$, making its barrier role for Coccinia even more difficult to understand.

\section{Conclusions}

The at least six biome shifts among the 27 species of Coccinia analyzed here may be an underestimate because of our assignments of species into just three broad biome types, semi-arid habitats, woodland, and forest. A fuller understanding of the physiological traits behind tolerated precipitation regimes in Coccinia would require transplants or common garden experiments [41]. The present results, based on occurrence data and ecological information from herbarium specimen labels, however show that changes in ecological 


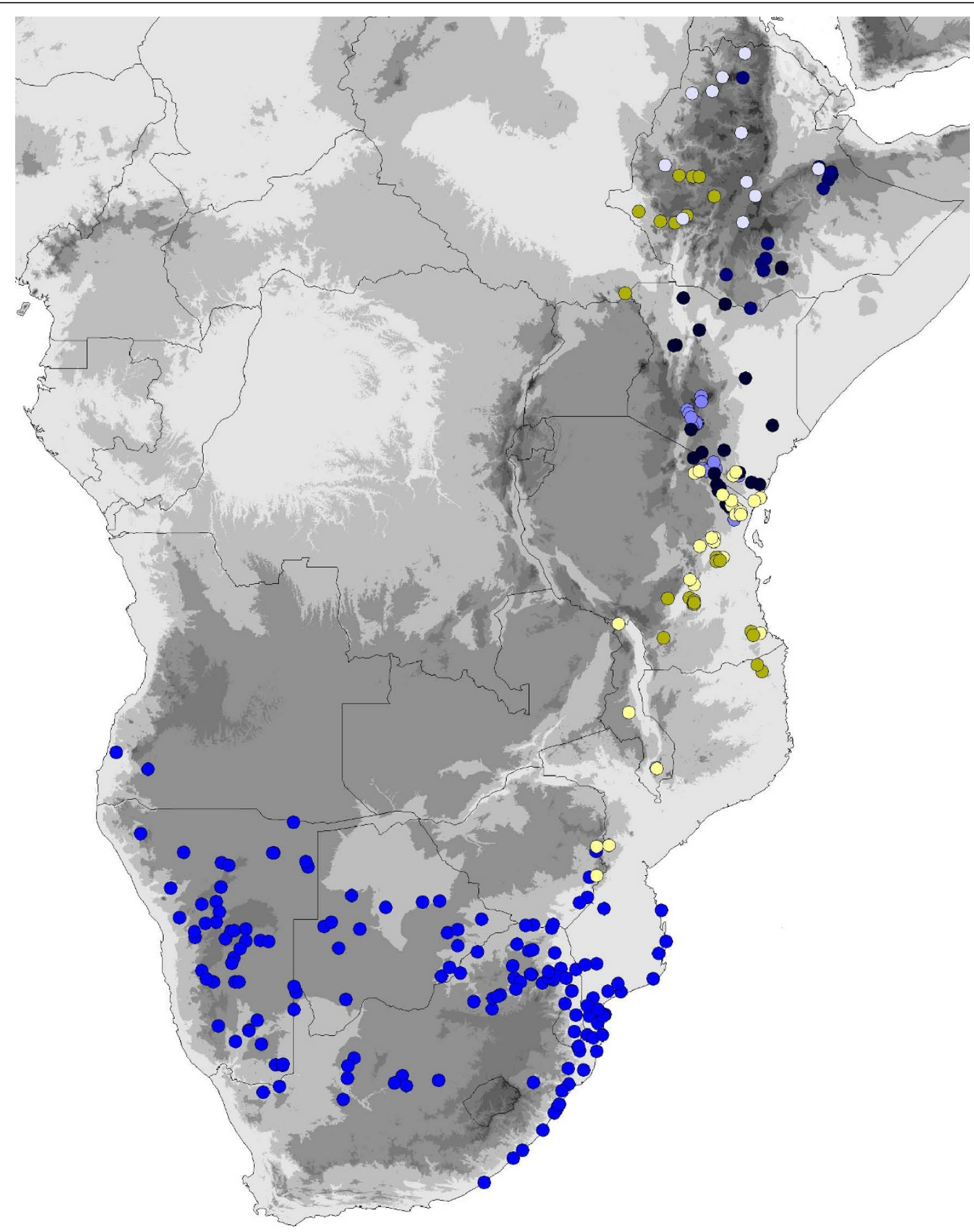

Figure 7 Distribution of C. grandiflora, C. schliebenii, and species of the Coccinia rehmannii clade. Bright blue (southern Africa) $=$ C. rehmannii, pale blue $=C$. trilobata, blackish blue $=C$. microphylla, ice-blue $=C$. abyssinica, dark blue $=C$. megarrhiza. Bright yellow $=C$. schliebenii, pale yellow $=$ C. grandiflora.

tolerances (especially drought tolerance) have played an important role in the diversification of Coccinia. A strength of this study is that it is based on consistent species concepts and geo-referenced data for well over 1000 collections.

\section{Methods}

Species Distribution Analysis and Biome Coding for Ancestral State Reconstruction

The first author surveyed c. 1400 specimens from 25 herbaria (B, BM, BR, COI, DSM, E, EA, FT, GAT, 
GOET, H, HBG, HEID, K, M, MO, MSB, NHT, P, S, UBT, WAG, and partly C, LISC, and LISU). Collecting localities (and some ecological information) were taken from herbarium specimen labels and geo-referenced 1189 of them with Google Earth, Google Maps (Google Inc., Mountain View, CA, USA), and online maps of the Perry-Castañeda Library Map Collection (http://www.lib. utexas.edu/maps/). Climate data were extracted from the WorldClim database (http://www.worldclim.org; [42]) using DIVA-GIS 7.1.6.2 (http://www.diva-gis.org). The number of arid months was calculated by counting how often the arithmetic mean of the monthly minimum and maximum temperature $\left[{ }^{\circ} \mathrm{C}\right]$ is larger than half of the monthly precipitation [mm] [43]. For ancestral state reconstruction, we assigned 24 species to one of three habitat categories: Semi-arid habitats (which includes semi-desert, bushlands, semi-arid savannas), woodland (including habitats such as mountain shrublands, humid grasslands, semi-humid savannas), or forest (including semi-deciduous forest, lowland rain forest, and mountain forest). Assignment of specimens/species to habitats followed information given on herbarium specimen labels and the WorldClim data for the respective location. Coccinia grandis, which occurs in African bushlands and savannas as well as in ruderal sites throughout the humid tropics, was coded as "semi-arid habitats" to reflect its drought tolerance.

Differences in annual precipitation and number of arid months tolerated by members of a species pair or a small clade were tested by pair-wise Mann-Whitney U tests in SPSS 13.0 (SPSS, Chicago, IL, USA). Trait reconstructions were carried out in Mesquite 2.71 [44] under maximum likelihood optimization, using the maximum clade credibility tree (with median heights) from the plastid DNA data obtained from BEAST (below) and Lewis' [45] Markov k-state one parameter model.

Finally, we tested whether the number of pairs of species in which members share the same niche preferences differs from that obtained if species habitat distributions were distributed on the tree at random.

\section{Molecular Phylogenetic Taxon Sampling and Methods}

We sampled 25 of the 27 species of Coccinia for several plastid and/or nuclear DNA markers. Only the poorly collected species Coccinia pwaniensis Holstein [46] and C. variifolia A. Meeuse could not be included. Trees were rooted on four outgroups, Cucumis sativus, Cucumis hirsutus, Peponium vogelii, and Scopellaria marginata, based on studies that included species from all African genera of Cucurbitaceae $[47,48]$. DNA was extracted from 3 - $20 \mathrm{mg}$ of leaf tissue from herbarium specimens or silica-dried plant material, using Macherey-Nagel plant extraction kits (Macherey-Nagel, Düren, Germany). For some samples, the lysis buffer was altered by adding sodium meta bisulfite (S9000, Sigma-Aldrich Chemie GmbH, Munich, Germany) to a $10 \mathrm{mM}$ final concentration [49]. PCR reactions used standard conditions, except for the addition of bovine serum albumine (Fermentas, St. Leon-Rot, Germany). We amplified the plastid intergenic spacers $\operatorname{trn} \mathrm{S}^{\mathrm{GCU}}$ trn $\mathrm{G}^{\mathrm{UCC}}$ and the rpl20-rps 12 using the primers of Hamilton et al. [50], the $n d h \mathrm{~F}-r p l 32$ spacer using the primers of Shaw et al. [51], the matK gene and $\operatorname{trnK}$ intron using the primers of Yokoyama et al. [52], and the $\operatorname{trn} \mathrm{L}^{\mathrm{UAA}}$ intron and $\operatorname{trn} \mathrm{L}^{\mathrm{UAA}}-\operatorname{trn} \mathrm{F}^{\mathrm{GAA}}$ spacer using the universal primers of Taberlet et al. [53]. PCR products were checked on a $1 \%$ agarose gel, and those with multiple bands were run on a $2 \%$ agarose gel, cut, and treated with the Wizard SV PCR clean-up kit (Promega $\mathrm{GmbH}$, Mannheim, Germany), following the manufacturer's instructions. Phusion high fidelity DNA Polymerase (Finnzymes, Espoo, Finland) was used for recalcitrant and low-concentrated samples and to amplify the $2^{\text {nd }}$ intron in the nuclear $L F Y$ gene. Primers for this region came from Volz and Renner [54] and from a M.Sc. thesis carried out in our lab [55]: LFYubiq F1: 5'-CAY CCN TTY ATH GTN CAN GAR CC-3'; LFYubiq-R1: 5'-GCR TAR CAR TGN ACR TAR TGN CKC AT- 3'.

The complete ITS region was amplified using the primers of Balthazar et al. [56]. Where necessary, we used cloning to assess within-plant sequence divergence, focusing on the polymorphic species. For cloning, we ligated PCR products into plasmids of the Promega pGEM-T Vector system (Promega). Plasmids were transformed in ultra competent E. coli DH5alpha strains [57]. Positive (white) plasmid colonies were picked from the ampicillin blue/white selection agar plates, solved in $4 \mathrm{ml} \mathrm{LB}$ medium with $100 \mathrm{mg} / \mathrm{ml}$ ampicillin, and grown over-night at $37^{\circ} \mathrm{C}$. Plasmids were obtained using GeneElute Miniprep Kit (Sigma-Aldrich) and directly amplified with primer oligonucleotides and settings as mentioned above. PCR products were purified and sequenced, using the same primers. Sequencing was performed on an ABI Prism 3130 Avant capillary sequencer using Pop-7 polymer (Applied Biosystems, Foster City, CA, USA), and sequences were edited with Sequencher v. 4.6 (Gene Codes, Ann Arbor, MI, USA).

\section{Alignment, Phylogenetic Inference and Divergence Time Estimation}

Sequences were aligned by eye, using MacClade v. 4.06 [58]. We excluded ambiguously alignable regions and structurally homoplastic sections. This concerned a total of 219 alignment positions in the plastid data (mostly microsatellites) and 42 nucleotides in the nuclear $L F Y$ matrix. Tree inference relied on maximum likelihood and was carried out in RAxML v. 7.2.2 [59], with the 
final parameter evaluation done under the GTR $+\Gamma$ substitution model. We used this model to approximate the best-fit models found with Modeltest v. 3.7 [60], which under a hierarchical likelihood ratio test indicated the $\mathrm{F} 81+\mathrm{I}+\Gamma$ model as the best fit for the combined plastid data, while under the Akaike information criterion it found TVM $+I+\Gamma$ as the best fit. Statistical support for individual nodes was assessed via bootstrapping with 100 replicates [61]. Nucleotide insertions and deletions (indels) were plotted on the resulting tree to test whether they contained phylogenetic information.

Divergence times were inferred using the program BEAST v. 1.5.2 [62], which employs a Bayesian Markov chain Monte Carlo (MCMC) approach to co-estimate topology, substitution rates, and node ages. The input data consisted of a matrix comprising 26 accessions from 24 species of Coccinia (C. mackenii and C. quinqueloba had identical sequences, and the former was therefore removed) and six outgroup accessions. There are no Coccinia fossils, and we therefore used a secondary calibration from a fossil-calibrated Cucurbitaceaewide dating analysis [48] that obtained an age of 15 million years $(\mathrm{Ma})$, with a standard deviation of $3.0 \mathrm{Ma}$, for the split between Coccinia and Diplocyclos. We used this age as a prior constraint on the root node of Coccinia, with a normal distribution and a standard deviation (SD) of 2.6 Ma. A SD of $2.7 \mathrm{Ma}$ (or larger) resulted in poor convergence of the MCMC chain. We used a strict clock model (which we preferred because we have a single secondary constraint), a Yule process tree prior, and MCMC chains of 10 million generation length, with parameters sampled every $1000^{\text {th }}$ generation. The first $20 \%$ of the trees was discarded as burn-in, and convergence and mixing of the chain were assessed by consistency across runs, inspection of trace plots in the program TRACER v. 1.4.1 [62], and from the effective sample sizes (ESS), which were well above 1000 for all estimated parameters. Four independent BEAST runs yielded the same maximum clade credibility topology, and we also ran an analysis without the data to verify that the effective priors do not contradict the original priors and to assess the informativeness of the data. The cut-off for nodes to be considered in the chronogram was $\geq 0.98$ posterior probability.

\section{Acknowledgements}

We thank R. E. Ricklefs for help with statistics and two reviewers whose insightful comments greatly improved our manuscript. The work was supported by the German Research Council (DFG RE603/6-1).

\section{Authors' contributions}

$\mathrm{NH}$ generated sequences and alignments, distribution data, performed data analyses, and worked on the manuscript. SSR conceived the study and drafted the manuscript. Both authors read and approved the final manuscript.
Received: 1 June 2010 Accepted: 26 January 2011

Published: 26 January 2011

\section{References}

1. Wiens JJ, Graham CH: Niche conservatism: integrating evolution, ecology, and conservation biology. Annual Review of Ecology, Evolution, and Systematics 2005, 36:519-539.

2. Crisp MD, Arroyo MTK, Cook LG, Gandolfo MA, Jordan GJ, McGlone MS, Weston PH, Westoby M, Wilf P, Linder HP: Phylogenetic biome conservatism on a global scale. Nature 2009, 458:754-756.

3. Peterson AT, Soberón J, Sánchez-Cordero V: Conservatism of ecological niches in evolutionary time. Science 1999, 285:1265-1267.

4. Dauby G, Duminil J, Heuertz M, Hardy OJ: Chloroplast DNA polymorphism and phylogeography of a Central African tree species widespread in mature rainforests: Greenwayodendron suaveolens (Annonaceae). Tropical Plant Biology 2010, 3:4-13.

5. Born C, Alvarez N, McKey D, Ossari S, Wickings EJ, Hossaert-McKey M, Chevallier $\mathrm{M}-\mathrm{H}$ : Insights into the biogeographical history of the Lower Guinea forest domain: evidence for the role of refugia in the intraspecific differentiation of Aucoumea klaineana. Molecular Ecology 2011, 20:131-142.

6. Lowe AJ, Harris D, Dormontt E, Dawson IK: Testing putative African tropical forest refugia using chloroplast and nuclear DNA phylogeography. Tropical Plant Biology 2010, 3:50-58.

7. Debout GDG, Doucet JL, Hardy OJ: Population history and gene dispersal inferred from spatial genetic structure of a Central African timber tree, Distemonanthus benthamianus (Caesalpinioideae). Heredity 2011, 106:88-99.

8. Muchugi A, Lengkeek AG, Kadu CAC, Muluvi GM, Njagi ENM, Dawson IK: Genetic variation in the threatened medicinal tree Prunus africana in Cameroon and Kenya: Implications for current management and evolutionary history. South African Journal of Botany 2006, 72:498-506.

9. Davis CC, Bell CD, Fritsch PW, Mathews S: Phylogeny of AcridocarpusBrachylophon (Malpighiaceae): implications for Tertiary tropical floras and Afroasian biogeography. Evolution 2002, 56:2395-2405.

10. Couvreur T, Chatrou L, Sosef MSM, Richardson J: Molecular phylogenetics reveal multiple tertiary vicariance origins of the African rain forest trees. BMC Biology 2008, 6:54

11. Kier G, Mutke J, Dinerstein E, Ricketts TH, Küper W, Kreft H, Barthlott W: Global patterns of plant diversity and floristic knowledge. Journal of Biogeography 2005, 32:1107-1116.

12. Küper W, Sommer JH, Lovett JC, Barthlott W: Deficiency in African plant distribution data - missing pieces of the puzzle. Botanical Journal of the Linnean Society 2006, 150:355-368.

13. Pickford M: Uplift of the roof of Africa and its bearing on the evolution of mankind. Human Evolution 1990, 5:1-20.

14. Kingston JD, Hill A, Marino BD: Isotopic evidence for Neogene hominid paleoenvironments in the Kenya Rift Valley. Science 1994, 264:955-959.

15. van Zinderen Bakker EM, Mercer JH: Major late Cainozoic climatic events and palaeoenvironmental changes in Africa viewed in a world wide context. Palaeogeography, Palaeoclimatology, Palaeoecology 1986, 56:217-235.

16. Axelrod DI, Raven PH: Late Cretaceous and Tertiary vegetation history of Africa. In Biogeography and Ecology of Southern Africa. Edited by: Werger MJA. The Hague: W. Junk bv Publishers; 1978:77-130.

17. Jacobs BF: Palaeobotanical studies from tropical Africa: relevance to the evolution of forest, woodland and savannah biomes. Philosophical Transactions of the Royal Society London - B 2004, 359:1573-1583.

18. Cerling TE, Harris JM, MacFadden BJ, Leakey MG, Quade J, Eisenmann V, Ehleringer JR: Global vegetation change through the Miocene/Pliocene boundary. Nature 1997, 389:153-158.

19. Sepulchre P, Ramstein G, Fluteau F, Schuster M, Tiercelin J-J, Brunet M: Tectonic uplift and Eastern Africa aridification. Science 2006, 313:1419-1423

20. Zachos J, Pagani M, Sloan L, Thomas E, Billups K: Trends, rhythms, and aberrations in global climate 65 Ma to present. Science 2001, 292:686-693.

21. deMenocal PB: Plio-Pleistocene African climate. Science 1995, 270:53-59.

22. Dupont $L M$, Jahns $S$, Marret F, Ning S: Vegetation change in equatorial West Africa: time-slices for the last $150 \mathrm{ka}$. Palaeogeography, Palaeoclimatology, Palaeoecology 2000, 155:95-122. 
23. Gasse F: Hydrological changes in the African tropics since the Last Glacial Maximum. Quaternary Science Reviews 2000, 19:189-211.

24. Elenga H, Maley J, Vincens A, Farrera I: Paleoenvironments, palaeoclimates and landscape development in Atlantic equatorial Africa: a review of key sites covering the last 25 kyrs. In Past climate variability through Europe and Africa. Edited by: Battarbee RW, Gasse F, Stickley CE. Dordrecht: Kluwer Academic Publishers; 2004:181-198.

25. Maley J: Fragmentation de la forêt dense humide africaine et extension des biotopes montagnardes au Quaternaire récent: nouvelles données polliniques et chronologiques. Implications paléoclimatiques et biogéographiques. In Palaeoecology of Africa and the surrounding islands. Volume 18. Edited by: Coetzee JA. Rotterdam, The Netherlands: A. A. Balkema; 1987:307-334.

26. Colyn M, Gautier-Hion A, Verheyen W: A re-appraisal of palaeoenvironmental history in central Africa: evidence for a major fluvial refuge in the Zaire basin. Journal of Biogeography 1991, 18:403-407.

27. Sosef MSM: Begonias and African rain forest refuges: General aspects and recent progress. Dordrecht, The Netherlands: Kluwer Academic Publishers; 1996.

28. Leal ME: Microrefugia, small scale ice age forest remnants. Systematics and Geography of Plants 2001, 71:1073-1077

29. Marret F, Maley J, Scourse J: Climatic instability in west equatorial Africa during the mid- and late Holocene. Quaternary International 2006, 150:71-81.

30. Maley J: A catastrophic destruction of African forests about 2,500 years ago still exerts a major influence on present vegetation formations. IDS Bulletin 2002, 33:13-30.

31. Jeffrey C: Cucurbitaceae. In Flora of Tropical East Africa. Edited by: MilneRedhead E, Polhill RM. London: Crown Agents for Oversea Governments and Administrations; 1967:157.

32. Zimmermann A: Die Cucurbitaceen. Jena: Gustav Fischer; 19222.

33. Cowling SA, Cox PM, Jones CD, Maslin MA, Peros M, Spall SA: Simulated glacial and interglacial vegetation across Africa: implications for species phylogenies and trans-African migration of plants and animals. Global Change Biology 2008, 14:827-840.

34. Fjeldså J, Lovett JC: Geographical patterns of old and young species in African forest biota: the significance of specific montane areas as evolutionary centres. Biodiversity and Conservation 1997, 6:325-346.

35. Salzmann U, Hoelzmann P: The Dahomey Gap: an abrupt climatically induced rain forest fragmentation in West Africa during the late Holocene. The Holocene 2005, 15:190-199.

36. Bhatt D, Kumar A: Foraging ecology of red-vented bulbul Pycnonotus cafer in Haridwar, India. Forktail 2001, 17:109-110.

37. Bleher B, Potgieter CJ, Johnson DN, Böhning-Gaese K: The importance of figs for frugivores in a South African coastal forest. Journal of Tropical Ecology 2003, 19:375-386.

38. Walter H, Breckle S-W: Ökologie der Erde. München: Elsevier, 32004.

39. Lorenzen ED, Masembe C, Arctander P, Siegismund HR: A long-standing Pleistocene refugium in southern Africa and a mosaic of refugia in East Africa: insights from mtDNA and the common eland antelope. Journal of Biogeography 2010, 37:571-581.

40. Freitag S, Robinson TJ: Phylogeographic patterns in mitochondrial DNA of the ostrich (Struthio camelus). The Auk 1993, 110:614-622.

41. Araya YN, Silvertown J, Gowing DJ, McConway KJ, Linder HP, Midgley G: A fundamental, eco-hydrological basis for niche segregation in plant communities. New Phytologist 2011, 189:253-258.

42. Hijmans RJ, Cameron SE, Parra JL, Jones PG, Jarvis A: Very high resolution interpolated climate surfaces for global land areas. International Journal of Climatology 2005, 25:1965-1978.

43. Gaussen $\mathrm{H}$ : Théorie et elassification des climats et microclimats. In: VIIle Congrès international de botanique: 2-14 July 1954 Paris; 1954, 125-130.

44. Maddison WP, Maddison DR: Mesquite: a modular system for evolutionary analysis., 2.712009

45. Lewis PO: A likelihood approach to estimating phylogeny from discrete morphological character data. Systematic Biology 2001, 50:913-925.

46. Holstein N, Renner SS: Coccinia (Cucurbitaceae) gains two new species from East Africa, three new synonyms, and one new combination. Kew Bulletin 2010, 65:435-441.

47. Kocyan A, Zhang L-B, Schaefer H, Renner SS: A multi-locus chloroplast phylogeny for the Cucurbitaceae and its implications for character evolution and classification. Molecular Phylogenetics and Evolution 2007, 44:553-577.

48. Schaefer H, Heibl C, Renner SS: Gourds afloat: a dated phylogeny reveals an Asian origin of the gourd family (Cucurbitaceae) and numerous oversea dispersal events. Proceedings of the Royal Society B: Biological Sciences 2009, 276:843-851.

49. Horne EC, Kumpatla SP, Patterson KA, Kupta M, Thompson SA: Improved high-throughput sunflower and cotton genomic DNA extraction and PCR fidelity. Plant Molecular Biology Reporter 2004, 22:83a-83i.

50. Hamilton MB: Four primer pairs for the amplification of chloroplast intergenic regions with intraspecific variation. Molecular Ecology 1999, 8:521-523.

51. Shaw J, Lickey EB, Schilling EE, Small RL: Comparison of whole chloroplast genome sequences to choose noncoding regions for phylogenetic studies in angiosperms: the tortoise and the hare III. American Journal of Botany 2007, 94:275-288.

52. Yokoyama J, Suzuki M, Iwatsuki K, Hasebe M: Molecular phylogeny of Coriaria, with special emphasis on the disjunct distribution. Molecular Phylogenetics and Evolution 2000, 14:11-19.

53. Taberlet $P$, Gielly L, Pautou G, Bouvet J: Universal primers for amplification of three non-coding regions of chloroplast DNA. Plant Molecular Biology 1991, 17:1105-1109.

54. Volz SM, Renner SS: Hybridization, polyploidy, and evolutionary transitions between monoecy and dioecy in Bryonia (Cucurbitaceae). American Journal of Botany 2008, 95:1297-1306.

55. Schuster K: The evolution of the Echinopsis huascha clade (Cactaceae), using molecular-phylogenetic methods. München: Ludwig-MaximiliansUniversität; 2009.

56. Balthazar Mv, Endress PK, Qiu Y-L: Phylogenetic relationships in Buxaceae based on nuclear Internal Transcribed Spacers and plastid $n d h F$ sequences. International Journal of Plant Sciences 2000, 161:785-792.

57. Inoue $\mathrm{H}, \mathrm{Nojima} H$, Okayama $\mathrm{H}$ : High efficiency transformation of Escherichia coli with plasmids. Gene 1990, 96:23-28.

58. Maddison WP, Maddison DR: MACCLADE: analysis of phylogeny and character evolution. Sunderland, MA: Sinauer Associates; 2.712003.

59. Stamatakis A, Ludwig T, Meier H: RAxML-III: a fast program for maximum likelihood-based inference of large phylogenetic trees. Bioinformatics 2005, 21:456-463.

60. Posada D, Crandall KA: MODELTEST: testing the model of DNA substitution. Bioinformatics 1998, 14:817-818.

61. Stamatakis A, Hoover $P$, Rougemont J: A rapid bootstrap algorithm for the RAxML web servers. Systematic Biology 2008, 57:758-771.

62. Drummond A, Rambaut A: BEAST: Bayesian evolutionary analysis by sampling trees. BMC Evolutionary Biology 2007, 7:214.

doi:10.1186/1471-2148-11-28

Cite this article as: Holstein and Renner: A dated phylogeny and collection records reveal repeated biome shifts in the African genus Coccinia (Cucurbitaceae). BMC Evolutionary Biology 2011 11:28.

\section{Submit your next manuscript to BioMed Central and take full advantage of:}

- Convenient online submission

- Thorough peer review

- No space constraints or color figure charges

- Immediate publication on acceptance

- Inclusion in PubMed, CAS, Scopus and Google Scholar

- Research which is freely available for redistribution

Submit your manuscript at www.biomedcentral.com/submit
C Biomed Central 